\title{
ОТНОШЕНИЯ ДУБРОВНИКА И БОСНИИ В ПЕРИОД ПРАВЛЕНИЯ БАНА СТЕПАНА II
}

\author{
() 2020 Д.А. Коряков \\ Нижегородский государственный университет им. Н.И. Лобачевского
}

Статья поступила в редакцию 05.12.2020

\begin{abstract}
Данная статья посвящена анализу отношений Боснии и Дубровницкой республики во второй четверти XIV века. Хронологические рамки исследования - с 1322 по 1353 год, период правления бана Степана II Котроманича. В этот период начинается экономическое и политическое усиление Боснии, и поэтому важно рассмотреть, как развивались ее отношения с важнейшим экономическим игроком Балканского полуострова. На основе доступных дубровницких источников сформирована картина отношений двух государств. В результате автор приходит к выводу, что отношения Боснии и Дубровника были в целом мирными, хоть и осложненными. Они стали основой для сотрудничества двух государств во второй половине XIV века.

Ключевые слова: Босния, Дубровник, международные отношения, дипломатия.
\end{abstract}

DOI: $10.37313 / 2658-4816-2020-2-4-52-59$

Босния как политическое образование появляется в X веке. K XIV веку она являлась зависимым от Венгрии государством, оставаясь во многом самостоятельной во внутренних делах. В 1322 году во главе ее встал Степан II Котроманич, который правил до 1353 года. В этот период произошел территориальный рост Боснии, она развивала отношения со своими соседями. Одним из ее соседей была Дубровницкая республика, важный торговый, экономический игрок на Балканах. B XIV веке начинается военный и экономический подъем Боснии, и она достигнет пика своего могущества при Твртко, наследнике Степана II. Тогда же Босния и Дубровник будут поддерживать крепкие связи. Но основа для отношений двух стран была заложена ранее, в период правления Степана II. Отношения Боснии и Дубровника отражены главным образом в документах Дубровника - в записях решений заседаний советов республики, коими

$\overline{\text { Коряков Дмитрий Алексеевич, документовед }}$ Сербского центра Нижегородского государственного университета им. Н.И. Лобачевского.

E-mail: koriakov.dmitrij2010@yandex.ru были Consilium maius, Consilium minus и Consilium rogatorum.

Дубровник, являясь торговой республикой, развивал свои экономические связи. Поэтому в отношениях с Боснией прослеживался и экономический интерес. Дубровницкие торговцы торговали в Боснии, через нее товары следовали транзитом в Венгрию. За указанный период известно несколько торговых караванов, которые отправлялись ${ }^{1}$ в Боснию в 1325, 1326 и 1332 гг. Караванные перевозки товаров, необходимые торговцам, развивались в течение XIV в. и XV в., и их маршруты становились все более разнообразными ${ }^{2}$. О наличии торговцев в Боснии говорит и тот факт, что дубровчане стали назначать для них своих консулов, которые разрешали их споры ${ }^{3}$. Из одного документа, датированного 1331 г., мы знаем, что имущество купцов Дубровника, торговавших в Боснии, оценивалось в 25 тысяч перперов ${ }^{4}$. К сожалению, нет возможности сравнить эту оценку с оценкой или данными более ранних и более поздних лет, чтобы проследить динамику.

Очень важным для торговли был торг Дриева, находившийся с середины 20-х гг. 
под властью Боснии. Это было одно из нескольких мест, где была разрешена торговля солью. Однако там также торговали вином, маслом, тканями, зерном, скотом, мясом, сыром, кожей, воском, древесиной, металлами и даже рабами. Вино и ткани не всегда были произведены в Дубровнике, а могли привозиться и из других мест, обычно из городов Италии, а за пределы Дубровника вывозились металлы ${ }^{5}$. Дубровчане становились откупщиками таможни в Дриеве, о чем свидетельствуют источники . Также во время правления Степана II в Боснии начинается открытие рудников ${ }^{7}$. Уже тогда серебро становится важнейшим товаром, который привлекает не только дубровчан, но и торговцев из других городов Адриатики ${ }^{8}$. Все это говорит о том, что дубровчане были заинтересованы в развитии экономических связей с Боснией, что способствовало установлению и развитию политических контактов.

Отношения Боснии и Дубровника не были бесконфликтными. Уже летом 1322 года бан Боснии Степан II отнял товары у сына Marini de Menze. Поэтому в ноябре 1322 года дубровчане дают указание трем отправляющимся в Боснию торговцам, чтобы они добились компенсации, для чего им следует встретиться с самим баном, его матерью et cum baronibus Bossine. В случае отказа торговцы должны покинуть Боснию к ближайшей пасхе, а на отправление в Боснию накладывался бы запрет. За нарушение данных запретов предусматривался достаточно высокий штраф в 500 перперов ${ }^{9}$. Сам Marinus de Menze был представителем большого, богатого и влиятельного рода de Menze, представители которого играли важную роль в политической и экономической жизни республики ${ }^{10}$. Поэтому данная проблема не могла остаться без внимания и активных действий со стороны Дубровника. В научной литературе встречается мнение, что бан Степан II арестовал самого сына Marini de Menze ${ }^{11}$, однако из текста документа можно сделать вывод лишь о конфискации товаров. Также встречается мнение, что конфискация произошла в 1321 году ${ }^{12}$, но слова in estate proxime preterita говорят о том, что события произошли в ближайшее прошедшее лето, то есть в 1322 году. Кроме того, маловероятным кажется то, что Дубровник среагировал бы спустя год со дня того события.

Тем не менее послы, судя по всему, не смогли договориться. В конце мая 1323 года Дубровник отправил своего посла к Степану II по поводу сына Marini de Menze, а также для договоренности о свободе передвижения дубровницких купцов и личной и имущественной безопасности. Половину расходов на содержание посольства платил сам Marinus de Menze ${ }^{13}$. Такая личная заинтересованность говорит о том, что проблема с его сыном не была решена до отправления данного посольства. Следует отметить тот факт, что данные события разворачивались в конце мая, то есть после пасхи, крайнего срока, когда дубровницкие купцы должны были уехать из Боснии. Возможно, именно это поспособствовало тому, что Босния пошла на уступки. О дальнейшей судьбе сына Marini de Menze документы не сообщают, что, вероятно, свидетельствует о том, что данный инцидент был исчерпан.

В литературе встречается мнение, что в решении спора помогла мать бана ${ }^{14}$. Об этом, в частности, повествует хроника более позднего периода, в которой некоторые события отнесены не к тому году, в котором они произошли. В хронике сказано, что в Боснию к матери бана отправились два посла, Nicolo di Ravi и Michiel Menze. Отправлялись они из-за неких новшеств, принятых баном Боснии по отношению к дубровницким купцам, что противоречило старым договоренностям ${ }^{15}$. Документы не сообщают о том, вводил ли Степан II новые правила для купцов, а два посла по имени Nichifor de Rania и Michel de Menze, отправляющиеся в Боснию, упоминаются в 1324 году ${ }^{16}$. Возможно, что в данном упоминании в хронике два или несколько событий были представлены как одно, и в этом случае можно предположить, что мать бана, к которой 
отправлялись послы еще в 1322 году, могла поспособствовать разрешению ситуации.

В марте 1324 года Дубровник готовился отправить двух послов к боснийскому бану, которые должны были подарить ему продуктов и других подарков на 150 перперов ${ }^{17}$. K сожалению, документ сообщает лишь, что послы отправляются in servitio communis, без каких-либо подробностей. Есть мнение ${ }^{18}$, что Босния стала посредником в разрешении конфликта Сербии и Дубровника, возникшего из-за дубровницкого купца Menze ${ }^{19}$. Другие историки не упоминают посредничества Боснии в разрешении спора по поводу купца Менче Менчетича ${ }^{20}$ либо упоминают, что данное посольство было направлено для совместных действий против Бранивоевичей ${ }^{21}$. Посредничество Боснии в данном случае выглядит маловероятным, так как вряд ли она обладала каким-либо дипломатическим весом в глазах сербского короля, а связи Сербии и Боснии в экономическом и политическом плане не были сильными, что уменьшало возможность для какого-либо влияния.

Отношения двух стран обострились в начале 1326 года. Тогда бан Степан II захотел получать десятую часть от стоимости дубровницких товаров в качестве платы за безопасный проход по его землям, а также грозился конфисковать товары. В ответ на это в начале февраля дубровчане запретили отправлять товары и отправляться лично в Боснию без разрешения князя под угрозой штрафа в 300 перперов. Для решения данной проблемы было решено отправить к бану послов ${ }^{22}$.

В литературе встречается предположение, что таможенные платежи не были отменены $^{23}$. Но даже несмотря на это боснийско-дубровницкие отношения продолжили развиваться в дружеском русле. Уже в конце марта 1326 года послы Дубровника готовились подарить Степану II ткани стоимостью 250 перперов, а также хлеб и вино стоимостью 30 перперов ${ }^{24}$, а в том же году в Боснию отправляется дубровницкий караван $^{25}$. Способствовала улучшению отно- шений и война с Бранивоевичами, отступниками сербского короля, в которой Босния и Дубровник оказались на одной стороне. В апреле было принято решение о совместных действиях против них, оговаривалось лишь, что договоренность не может рассматриваться как союз против Сербии ${ }^{26}$. Встречается мнение, что предложение о союзе поступило от боснийского бана ${ }^{27}$, хотя текст документа не дает нам сведений о том, что именно со стороны Боснии поступило такое предложение. Совместными действиями силы Бранивоевичей были разгромлены ${ }^{28}$, a их территория занята Боснией.

После занятия земель Бранивоевичей Босния стала граничить с Дубровником. Отношения их до конца 20-х годов оставались дружескими. Так, в феврале 1327 года Дубровник подарил матери бана и ее сыновьям ткани стоимостью 100 перперов. Сделано это, как отмечали дубровчане, не из долга, а из любви, которую госпожа баница и ее сыновья всегда проявляли по отношению к Дубровнику и его торговцам, которые в ее землях жили и находились ${ }^{29}$. Есть мнение, что тогда была восстановлена торговля между Боснией и Дубровником ${ }^{30}$, но это мнение неверно, так как и до этого, в 1326 году, в Боснию отправлялся дубровницкий караван ${ }^{31}$.

В июле того же года дубровчане готовились отправить двух торжественных послов для чествования Степана II и преподнести ему дары стоимостью 300 перперов, если он придет в Biscie $^{32}$. Однако вскоре дубровчане решили отправить гонца туда, где он находился, одновременно готовя и посольство $^{33}$, что говорит о том, что бан не прибыл в указанное место. Несомненно, данное намерение было продиктовано желанием республики поддержать установившиеся отношения и даже улучшить их. Подтверждает это и отсутствие в источнике упоминания о составлении инструкций и иных целей посольства. Кроме того, в Дубровнике видели возросшую военную мощь Боснии. В республике понимали, что в случае конфликта боснийский бан может нанести им большой 
ущерб ${ }^{34}$, поэтому поддержание хороших отношений им было крайне важно.

В 1328 году Дубровник отправил к бану Боснии трех послов, которые должны были обещать ему 1333 перпера и 4 гроша, если он убьет Vitomiro de Stai или если будет держать его в тюрьме до смерти ${ }^{35}$. Витомира, который управлял областями Требине, Конавле и Драчевица, дубровчане считали виновным в грабежах и борьбе против Дубровницкой республики во время войны с Бранивоевичами ${ }^{36}$. Дубровник пытался добиться его выдачи от короля Сербии в 1326 году, но данная попытка закончилась неудачей. Тогда дубровчане обратились за помощью к бану Боснии, который согласился помочь, после чего с начала 1329 года Витомир пропадает из политической жизни ${ }^{37}$. Это, безусловно, улучшило отношения двух стран. Летом 1329 года дубровчане дарят Степану II на свадьбу дорогие ткани ${ }^{38}$.

В 30-е гг. XIV в. отношения Дубровника и Боснии нередко были осложнены из-за грабежей торговцев. Прибавилась к этому и проблема выплаты могориша - дани за пользование землями, соседствующими с Дубровником. Так как с Дубровницкой республикой граничили Хум и Требине, то дань вначале платилась их князьям, а затем сербскому королю, когда эти земли вошли в состав Сербии. В XIII веке осталась лишь Хумская дань. Сами дубровчане обосновывали выплату дани защитой от нападений и грабежей, что давало им повод не выплачивать ее, если грабежи происходили ${ }^{39}$. Однако после поражения Бранивоевичей и внутренних неурядиц в Сербии, связанных с борьбой Стефана Душана и Стефана Дечанского, Хум был занят Боснией, и потому могориш уже не мог выплачиваться Сербии.

Начались трудности уже в январе 1331 года. Тогда Дубровник стал требовать от Rogerio, известного в сербской историографии как Ружир, и его людей, чтобы они не причиняли злодеяний дубровчанам, идущим через Хум или находящимся в Дриеве, угрожая принять против них меры ${ }^{40}$. Однако, судя по всему, данное требование не имело эффекта, и уже 3 сентября Дубровник отказался выплачивать Ружиру могориш, если он не выплатит компенсацию. Для этого к нему были отправлены два посла ${ }^{41}$. Кроме того, в Дубровник отправил письмо Степан II, который требовал выплаты ему могориша, угрожая нанесением ущерба в случае отказа. Для решения данной проблемы дубровчане подготовили посольство, которое должно было ждать прибытия бана в Хум, после чего прибыть к нему. Они же должны были преподнести дары - ткани стоимостью 200 перперов ${ }^{42}$.

Однако Степан II, судя по всему, в Хум не прибыл, и посольство было отложено. О его подготовке вновь заговорили в начале лета 1332 года. Тогда были выбраны три sapientes, которые должны составить указания для послов, а стоимость даров увеличили до 300 перперов ${ }^{43}$. Однако данное посольство, если оно было отправлено, не сумело разрешить спор. В июле 1332 года в ответ на требования выплаты могориша дубровчане писали, что эту дань они должны платить не королю Сербии, бану Боснии или князю Хума, a Dudich de Papua, и выплачивается она за охрану их владений. Если же им был нанесен ущерб, то республика может не выплачивать могориш ${ }^{44}$. В результате стороны договорились принять решение по могоришу на станаке - судебной встрече, на которой решались споры дубровчан и их соседей. На нем, кроме выплаты дани, следовало решить вопрос об ущербе, нанесенном людьми бана в Стоне, Polize и в Malfo. Тогда же Дубровник решил не предоставлять боснийскому бану до выплаты компенсаций две вооруженные барки, которые он просил ${ }^{45}$. Однако Степан II не приехал на встречу, поэтому она была перенесена на начало 1333 года. О том, чем закончился данный спор, источники умалчивают, известно лишь то, что право на получение могориша боснийский бан в то время не получил ${ }^{46}$. Что касается компенсаций, Ружир и другие феодалы Хума перешли на сторону Сербии в 1334-1335 гг. ${ }^{47}$, поэтому выплата компенсаций больше не являлась делом боснийско-дубровницких отношений. 
Следует отметить, что данный конфликт не нанес большого ущерба двусторонним связям. Так, например, в 1332-1333 гг. дубровчане стали посредниками в отношениях Боснии и Сербии ${ }^{48}$. В конце 1332 года бан Степан II издал грамоту, которая урегулировала некоторые вопросы взаимоотношений дубровчан с жителями Боснии. В ней, в частности, решался вопрос о подсудности во время имущественных тяжб дубровчан и бошнян, а также о подсудности дел, связанных с убийствами и кражами. Кроме того, боснийский бан обещал дубровчанам возможность свободно уехать в Дубровник в течение шести месяцев, если начнется война между Боснией и Дубровником ${ }^{49}$.

После победы над Бранивоевичами Дубровник стал прилагать усилия, чтобы получить во владение Стон и полуостров Пелешац. Данные территории сначала принадлежали Сербии, затем ими управляли Бранивоевичи, после их поражения эти земли успели побывать в руках сербского короля и боснийского бана ${ }^{50}$. В январе 1333 года Дубровник принял решение заплатить королю Сербии за получение Стона восемь тысяч перперов, а также платить по 500 перперов каждый год. Такую же ежегодную сумму дубровчане были готовы платить бану Боснии и его потомкам ${ }^{51}$. Уже в конце января сербский король Стефан Душан даровал Дубровнику грамоту, которой он уступал Стон, Пелешац, Сланское Приморье, которое соединяло Дубровник с указанными землями, и близлежащие острова за 8000 перперов и 500 перперов ежегодной дани ${ }^{52}$.

После получения этих земель от их законного владельца дубровчанам оставалось получить права на них от Боснии. Связано это было с тем, что Степан II некоторое время владел Стоном и Пелешацем, а к тому времени держал под своим контролем Сланское Приморье. Кроме того, так можно было обезопасить свои владения от аппетитов боснийского бана. Уже 7 февраля дубровчане из уважения к Степану Котроманичу дарили 60 перперов его человеку ${ }^{53}$. А три дня спустя был выбран послом Michael de Menze, он должен был договориться о передаче земель, которые Дубровнику даровал Стефан Душан. Бану Боснии обещали за это тысячу перперов ${ }^{54} .15$ февраля 1333 года Степан II Котроманич передал Дубровнику Стон и Превлаку за 500 перперов в год. Самому Степану и его потомкам дали обещание предоставить в случае необходимости дворец для пребывания в Дубровнике, а также обещали не принимать его отступников $^{55}$. О передаче Сланского Приморья в грамоте не было ничего сказано, поэтому полуостров Пелешац так и остался отрезан от территории Дубровника.

После этого позитивный характер боснийско-дубровницких отношений сохранялся некоторое время. В начале 1335 года в Хум к бану отправлялось посольство с дарами на 300 перперов. Подарки на такую же сумму были подарены и на свадьбу Степана II, которая состоялась летом того же года ${ }^{56}$.

Однако в том же году отношения вновь стали напряженными. В ноябре-декабре произошла серия грабежей дубровчан на Пелешаце ${ }^{57}$. В декабре Дубровник отправил посла к боснийскому бану для получения компенсаций, но уже в конце декабря был введен запрет на отправление торговцев в Боснию, а уже находящимся в Боснии торговцам сообщили, чтобы готовились уезжать $^{58}$, что говорит о том, что проблема стала гораздо более серьезной. Данные меры действовали и в следующем, 1336 году. Тогда Дубровник пошел навстречу просьбам боснийского воеводы Valchi, которому разрешили вывезти товары на сумму в 300 перперов ${ }^{59}$. Одновременно шли переговоры со Степаном II, который обещал выплатить компенсации, но не сдержал своего слова. Поэтому 10 июля 1336 года запрет на торговлю был оставлен в силе, а также было решено не платить дань в 500 перперов ${ }^{60}$. Однако уже в конце июля торговцам было разрешено отправляться в Боснию, был выбран посол, который должен был позаботиться о выплате оставшейся компенсации, а также было решено выплатить дань ${ }^{61}$. Это говорит о том, что бан выплатил часть 
компенсации. Поэтому они решили восстановить торговые связи. О дальнейших событиях документы умалчивают. Хроника сообщает о грабежах боснийцев в 1339 году и отправке двух послов к боснийскому бану ${ }^{62}$, но подробности данных событий неизвестны. В 1340 году дубровчане отправляют послов, которые должны были добиться получения от Боснии острова Posredniza, которую передал сербский король, но которая оставалась под контролем бана, однако их миссия окончилась неудачей ${ }^{63}$.

Следующие известные события относятся к 1344 году. В середине июня 1344 года готовилось дубровницкое посольство к Степану II, который прибыл в Хум, чтобы добиться получения всех земель и мест, которые пытались получить другие послы. Оно также должно было подарить бану 1100 грошей и его baronibus, videlibet uoyuode et aliis 600 перперов. Однако в конце июня дубровчане отказались от отправки посольства ${ }^{64}$. Судя по всему Дубровник пытался получить те земли, которые им передал Стефан Душан и которые фактически находились под контролем Боснии. То, что бану планировали подарить менее 100 перперов, а его феодалам 600, говорит о том, что дубровчане стремились повлиять через них на Степана II. Причины, по которым отправка посольства была отменена, неизвестны.

В октябре 1344 года Дубровник отправил послов к боснийскому бану и к de Nicolich, которые грабили дубровчан ${ }^{65}$. Несмотря на то, что грабителями оказались родственники бана, данные события, вероятно, не сильно навредили отношениям Боснии и Дубровника либо проблемы были решены, так как уже в январе 1345 года Дубровник предоставляет бану Стефану II по его просьбе снаряженную галеру с экипажем ${ }^{66}$. Следует также учесть, что предоставление галеры происходит во время войны в Далмации, в которой участвовали Венгрия, Босния и Венеция, которой подчинялась тогда Дубровницкая республика. Тогда же, в начале 1345 года, в Боснии находились дубровницкие послы, однако источники не сообщают, о чем велись переговоры ${ }^{67}$. Переговоры эти завершились неким обещанием бана, которое он не выполнил, и поэтому в апреле Дубровник отправляет послание Степану II и Junio Chalich, в котором просит бана отправить тех людей, которых обещал, и выполнить то, что обещал послам ${ }^{68}$. В данном случае источники опять не сообщают никаких подробностей. Нет никаких подробностей и о посольстве, которое отправилось к бану в середине 1346 года ${ }^{69}$.

В 1347 году вновь появилась проблема с de Nicolich, которые вновь занялись грабежами. Весной дубровчане сделали подарок homini domini bani Bossine по имени Craguy, а также отправили к нему посла, чтобы решить вопрос о компенсации ущерба ${ }^{70}$. В конце марта послы отправлялись уже не только к Craguy, но и к Степану II, чтобы пожаловаться на оскорбления, нанесенные Vladislauum и Boghissam Nicolich, племенниками бана ${ }^{71}$. Об окончании спора источники умалчивают. В июле 1348 года дубровчане решили пожаловаться сербскому королю, Nicole de Buchie, бану Боснии, его матери и любым другим лицам на ущерб, который нанесли им их соседи ${ }^{72}$. Так как жалобы были адресованы и Сербии, и Боснии, то грабителями, вероятнее всего, были правители пограничных с Дубровником сербских и боснийских земель. Источники вновь не сообщают о каких-либо результатах миссии.

В октябре 1348 года Степан II ввел запрет на нахождение дубровницких купцов в Боснии. О прямых причинах данного решения источник не сообщает. В ноябре в Дубровнике выбирались лица, которые должны были узнать, сколько будет длиться этот запрет, а также оценить ущерб от больших таможенных пошлин ${ }^{73}$. Одновременно дубровчане пытались задействовать и боснийских феодалов. Об этом, например, говорит и подарок в 40 перперов, подаренный Senco, barono d. bani bossine, когда тот находился в Дубровнике, a Junio de Calich было дано разрешение вывезти продукты из Дубровника ${ }^{74}$. Хроника более позднего периода сообщает не только о повышенных 
пошлинах, но и попытках решить проблему мирным путем. В ней же говорится о том, что боснийский бан с большим войском подошел к Брено, но в ходе нескольких столкновений был побежден и поэтому согласился решить вопрос мирно ${ }^{75}$. Маловероятно, что сведения хроники достоверны, так как они не нашли никакого отражения в документах советов Дубровника. Однако если эта хроника достоверна, то данные события могли произойти, вероятно, после весны 1349 года, так как в начале этого года все еще велись переговоры ${ }^{76}$. Достоверно о нормализации отношений известно из письма Степана II, отправленного в Дубровник в 1351 году. В данном письме он приглашал купцов приезжать и торговать в Боснии без страха, обещая законно и справедливо взимать долги со своих должников ${ }^{77}$.

Таким образом, боснийско-дубровницкие отношения в 1322-1353 гг., в период правления Степана II Котроманича, не были безоблачными, но в целом они оставались мирными. Босния, в отличие от Сербии, не воевала с Дубровником и даже на короткое время стала если не формальным, то фактическим союзником республики. Описание военного конфликта 1349 года в хронике, вероятнее всего, недостоверно, как и некоторые другие события того источника. Одной из частых проблем, которая осложняла отношения двух стран, были грабежи торговцев, для решения которой Дубровник был вынужден прибегать к дипломатии, а когда этого было недостаточно, то прибегал и к экономическим мерам. Однако к данной, безусловно, крайней мере республика прибегла лишь три раза. Спор по поводу выплаты могориша был решен дипломатически, но не окончательно, и в будущем республика станет платить ее правителю Боснии. Остальные конфликтные ситуации были решены исключительно путем дипломатии. В целом экономические и дипломатические отношения, установившиеся при Степане II, стали основой для отношений Дубровника и Боснии в период правления наследника Степана Твртко.

\section{ПРИМЕЧАНИЯ}

${ }^{1}$ Monumenta Ragusina. Libri reformationum. Tomus 2 (далее - MR 2). Zagrabia: Sumptibus Academiae scientiarum et atrium, 1882. P. 317, 342; Monumenta Ragusina. Libri reformationum. Tomus 5 (далее - MR 5). Zagrabia: Sumptibus Academiae scientiarum et atrium, 1897. P. 176, 212.

${ }^{2}$ Динић М. Дубровачка средњевековна караванска трговина // Из српске историје средњега века. Београд: Equilibrium, 2003. С. 696-697.

${ }^{3}$ Chronica Ragusina Junii Resti (ab origine urbis usque ad annum 1451) (далее - CR). Zagrabia, 1893. P. 123.

${ }^{4}$ MR 2. P. 336.

${ }^{5}$ Тошић Ђ. Трг Дријева у средњем вијеку. Сарајево: Веселин Маслеша, 1987. С. 83, 85, 89, 97-98.

${ }^{6}$ Порчић Н. Писмо бана Степана II Котроманића о разрешењу рачуна браће Држића // Грађа о прошлости Босне. 2009. № 2. С. 25-34; Ћирковић С. Писмо бана Стјепана II Котроманића кнезу и општини дубровачкој о дугу дубровачких трговаца // Грађа о прошлости Босне. 2008. № 1. С. 23-35.

${ }^{7}$ Kovačević D. Trgovina u srednjovekovnoj Bosni. Sarajevo, 1961. S. 18; Ћирковић С., КовачевићКојић Д., Ћук Р. Старо српско рударство. Београд - Нови Сад: Вукова задужбина - Прометеј, 2002. C. 46.

${ }^{8}$ Kovačević D. Op. cit. S. 19.

${ }^{9}$ Monumenta Ragusina. Libri reformationum. Tomus 1 (далее - MR 1). Zagrabia, 1879. P. 72.

${ }^{10}$ Манкен И. Дубровачки патрицијат у XIV веку. Београд: Научно дело, 1960. С. 314, 321.

${ }^{11}$ Klaić V. Poviest Bosne do propasti kraljevstva. Zagreb, 1882. S. 116.

${ }^{12}$ Ћоровић B. Хисторија Босне. Прва књига. Београд: Слово, 1940. С. 243.

${ }^{13}$ MR 1. P. 85.

${ }^{14}$ Ћоровић B. Op. cit. C. 243.

${ }^{15}$ CR. P. 113-114.

${ }^{16}$ MR 1. P. 115.

${ }^{17}$ Ibid.

${ }^{18}$ Tоровић B. Op. cit. C. 244.

${ }^{19}$ CR. P. 116.

${ }^{20}$ Манкен И. Указ. соч. С. 335; Јечменица Д. Стефан Душан и Дубровник: докторска дисертација. Београд, 2012. С. 31-32.

${ }^{21}$ Медини М. Дубровник Гучетића. Београд: Научна књига, 1953. С. 7.

${ }^{22}$ MR 5. P. 193-194; Ћоровић B. Op. cit. C. 243.

${ }^{23}$ Kovačević D. Op. cit. S. 16.

${ }^{24}$ MR 5. P. 196.

${ }^{25}$ Ibid. P. 212.

${ }^{26}$ Ibid. P. 198-199; Ћоровић В. Op. cit. C. 245-246; Foretić V. Povijest Dubrovnika do 1808. Prvi dio. Od osnutka do 1526. Zagreb: Nakladni zavod MH, 1980. S. 91; Мишић C. Хумска земља у средњем веку. Београд: Филозофски факултет, 1996. С. 57-58. 
27 Јечмениц̧а Д. Стефан Душан и Дубровник. C. 40 .

${ }^{28}$ Ibid. C. 34

${ }^{29}$ MR 5. P. 233.

${ }^{30}$ hopoвић B. Op. cit. C. 251.

${ }^{31}$ MR 5. P. 212.

${ }^{32}$ Ibid. C. 244-245.

33 Ibid. C. 246.

${ }^{34}$ MR 2. P. 336.

35 MR 5. P. 255.

${ }^{36}$ Медини М. Op. cit. С. 11.

${ }^{37}$ Јечменица Д. Стефан Душан и Дубровник. С. 79-82.

${ }^{38}$ MR 2. P. 323; MR 5. P. 266-267.

39 Динић M. Дубровачки трибути // Из српске историје средњега века. Београд: Equilibrium, 2003. С. 713-714.

${ }^{40}$ MR 2. P. 331.

${ }^{41}$ MR 2. Р. 336-337; MR 5. Р. 323-324; Јечменица Д. Стефан Душан и Дубровник. С. 129-130.

${ }^{42}$ MR 2. P. 337-338; MR 5. P. 326-327, 332-334.

${ }^{43}$ MR 2. P. 342; MR 5. P. 352.

${ }^{44}$ MR 2. P. 343; MR 5. Р. 356-357; Динић М. Дубровачки трибути. С. 720.

${ }^{45}$ MR 2. P. 344-345; MR 5. P. 363, 367-368.

${ }^{46}$ Динић М. Дубровачки трибути. С. 720.

${ }^{47}$ Ћоровић B. Op. cit. C. 255-256; Мuшuћ C. Op. cit. C. 62.

${ }^{48}$ MR 2. Р. 343-344; MR 5. Р. 360-362; Јечменица Д. Стефан Душан и Дубровник. C. 131-133.

${ }^{49}$ Поповић P. Повеља бана Стјепана II Котроманића о решавању спорова између Босне и Дубровника // Стари српски архив. 2007. № 6. С. 35-54.

${ }^{50}$ Muшuћ C. Op. cit. C. 60-61.

${ }^{51}$ MR 2. P. 347-348; MR 5. P. 374-375.

52 Јечменица Д. Стефан Душан и Дубровник. С. 142-148.
${ }^{53}$ MR 2. P. 348; MR 5. P. 378.

${ }^{54}$ MR 2. P. 349; MR 5. Р. 379; CR. Р. 125; Јечменица Д. Стефан Душан и Дубровник. С. 150.

55 Јечменица Д. Стонска повеља бана Стефана II Котроманића // Грађа о прошлости Босне. 2010. № 3. C. 29-46.

${ }^{56}$ MR 2. P. 354-355, 360; Јечменица Д. Стефан Душан и Дубровник. С. 169.

57 Јечменица Д. Стефан Душан и Дубровник. C. 166-167.

${ }^{58}$ MR 2. P. 362, 265; Јечменица Д. Стефан Душан и Дубровник. С. 167.

${ }^{59}$ MR 2. P. 365-366.

${ }^{60}$ Ibid. P. 367.

${ }^{61}$ Ibid. P. 367; MR 5. Р. 387; Јечменица Д. Стефан Душан и Дубровник. С. 167-168; Ћоровић В. Ор. cit. С. 256.

${ }^{62}$ CR. P. $128-129$.

${ }^{63}$ Ibid. P. 129.

${ }^{64}$ MR 1. P. 155-157.

${ }^{65}$ Ibid. P. 161-163; Muшuћ C. Op. cit. C. 62.

${ }^{66}$ MR 1. P. 169.

${ }^{67}$ Ibid. P. 170.

${ }^{68}$ Ibid. P. 173.

${ }^{69}$ Ibid. P. 236

${ }^{70}$ Ibid. P. 255, 258-259.

${ }^{71}$ Ibid. P. 259-260.

${ }^{72}$ MR 2. P. 31; Јечменица Д. Стефан Душан и Дубровник. С. 270.

${ }^{73}$ MR 2. P. 45, 51.

${ }^{74}$ Ibid. P. 46, 61.

${ }^{75}$ CR. P. 131.

${ }^{76}$ MR 2. P. 60-61, 68.

${ }^{77}$ Ibid. P. 139; Јечменица Д. Писмо бана Стефана II којим позива дубровачке трговце да слободно тргују у Босни // Грађа о прошлости Босне. 2012. № 5. C. 27-31.

\section{RELATIONS BETWEEN DUBROVNIK AND BOSNIA DURING THE REIGN OF BAN STEPAN II}

(C) 2020 D.A. Koryakov

\section{Lobachevsky State University of Nizhni Novgorod}

This article is devoted to the analysis of relations between Bosnia and the Dubrovnik Republic in the second quarter of the XIV century. The chronological framework of the study is from 1322 to 1353, the period of the reign of Ban Stjepan II Kotromanić. During this period, the economic and political strengthening of Bosnia begins, and therefore it is important to consider how its relations with the most important economic player of the Balkan Peninsula developed. Based on the available Dubrovnik sources, a picture of relations between the two states has been formed. As a result, the author comes to the conclusion that relations between Bosnia and Dubrovnik were generally peaceful, albeit complicated. They became the basis for cooperation between the two states in the second half of the XIV century.

Keywords: Bosnia, Dubrovnik, international relations, diplomacy.

DOI: $10.37313 / 2658-4816-2020-2-4-52-59$

Dmitry Koryakov, document specialist of the Serbian

Center of Lobachevsky State University of Nizhni

Novgorod.E-mail: koriakov.dmitrij2010@yandex.ru 